\title{
Evaluations of an entrepreneurship development program: A systematic literature review
}

\author{
Ronal Ferdilan ${ }^{1 *}$, Wawan Dhewanto ${ }^{2}$, Sonny Rustiadi ${ }^{3}$ \\ ${ }^{1}$ School of Business and Management, Institute of Technology Bandung, Bandung, \\ Indonesia \\ ${ }^{2}$ School of Business and Management, Institute of Technology Bandung, Bandung, \\ Indonesia \\ ${ }^{3}$ School of Business and Management, Institute of Technology Bandung, Bandung, \\ Indonesia \\ *Corresponding Author(s) Email: ronal-ferdilan@sbm-itb.ac.id
}

\section{ABSTRACT}

The contribution of entrepreneurship at both the microeconomic and macroeconomic levels is remarkable. There are many entrepreneurship development programs (EDP) initiatives proposed by policymakers around the world to ensure the growth of entrepreneurs. While EDP is necessary to improve entrepreneur capabilities, however studies on EDP evaluation literacy remain limited. This study aims to fill the gap by investigating EDP evaluation literacy by using a systematic literature review (SLR). This study carried out a bibliometric analysis on a Scopus database in the last three decades, from 1989 to 2021 with all the manuscripts were written in English. The results show that most of the literature on EDP evaluation-related themes is mainly focused on program evaluation, characteristics, challenges, stakeholders, and context, with program evaluation and characteristics are considered as the most significant issues of EDP evaluation. Interestingly, this study also reveals that few manuscripts review the process of EDP as the success criterion of EDP implementation.

Keywords: Entrepreneurship; Development; Small and Medium Enterprises (SMEs); Education; Training; Systematic Review; Bibliometric Analysis
JEL Code:

I25, I30, M13

DOI:

10.31106/jema.v18i2.11461

Article History:

Received 2021-07-08

Reviewed 2021-07-30

Revised 2021-08-02

Accepted 2021-08-19

Licensed:

CC-BY 


\section{Introduction}

Entrepreneurship development programs (EDP) are activities (or a package of training and counseling designed) to increase knowledge and creativity. EDP encourages the entrepreneurial spirit of people to start and grow their business in both formal (high-school and post-secondary school students) and informal sectors (Gangi, 2017; Hägg \& Gabrielsson, 2020; Lackéus, 2015; Valerio et al., 2014). The purposes of EDP are to improve skills, knowledge, and attitudes of targeted individuals and community (Fayolle et al., 2016; Gedeon, 2017; Klingler-vidra et al., 2019), to start a new business, and to add new jobs (Decker et al., 2014; Jeng \& Hung, 2019), to provide an alternatives sources of income (Dvouletý, 2017; Terjesen et al., 2016), and to initiate economic growth (Martínez et al., 2018; Song \& Winkler, 2014; Stoica \& Roman, 2020). Nowadays, EDP implementation is getting more recognition and attention from policymakers and academicians because of its contributions (Tsai et al., 2014). EDP offered many benefits to the entrepreneurial community. It increases the economic contribution, gives alternative solutions to youth unemployment issues, creates social impact, etc. (Nabi et al., 2017; Pettersson et al., 2017; Valerio et al., 2014).

The academic literature EDP-related has been expanding steadily over the years, covering themes like entrepreneurship program categorization, attitudes, and perception, EDP objective, program content and framework, social entrepreneurship, evaluation, and impact (Gabrielsson et al., 2020; Kakouris \& Georgiadis, 2016; Loi et al., 2016; Martin et al., 2013). However, Gustafsson-Pesonen \& Remes (2012) argued that despite its popularity, it's very often reported that the biggest obstacles of entrepreneurship programs are on what (and how) educators or trainers teach and their attitudes toward entrepreneurship. Besides, GustafssonPesonen \& Remes (2012) also pointed that the evaluation of the EDP effectiveness remains arguable. Fayolle (2013) added that while the impact of the program or session on trainees, students, and other participants may be an appropriate evaluation criterion, there is still the issue of how to measure it. What should the indicators be, and how should they be measured? How can you quantify a shift in someone's intention or behavior? How may the sign of the time component be considered? And how can educational, teaching, and training aspects be distinguished from all other factors that influence the decision to pursue a particular career path or profession?

The clear EDP evaluation measurement is necessary to provide tremendous program improvement of all deficiencies in achieving the program's goals and objectives and closing 
the loop of the program decision-making. Although there is still debate about evaluation measurement due to the absence of a control group (Fayolle, 2013) and meta-analysis (Bae et al., 2014), this problem can be minimized by analyzing its nature, educational interventions, and context. Therefore, to fill such a gap, the study aims to explore the state of EDP evaluations using a systematic literature review (SLR) since this method can give an exceptional knowledge of the current body of work (Frank \& Hatak, 2014). We have investigated 366 papers from the Scopus database that were published from 1989 to 2021 that used the keywords "entrepreneur," "develop," "evaluate," "education," and "training." The usage of Scopus as the primary database in the study is because this reputable international database is utilized by academicians worldwide. By investigating state of the art, we identified five main themes: evaluation, program characteristics, challenge, stakeholder, and context. Besides these central themes, we also evaluated the manuscript based on the period it was published, the contributors, and the subject area of the manuscript. This study is considered the first amongst EDP-related manuscripts that uses SLR to explore the evaluations of the EDP. Furthermore, the systemic literature review is used as this method can create an academic map regarding EDP evaluation trends and futures (Alvesson \& Sandberg, 2011).

The manuscript is composed as follows: the first and second sections will briefly review academic literature, concentrating specifically on the theme's critical aspect of EDP. Subsequently, the third section states the methodology of the research to produce a duplicable SLR. Following these come the results of the SLR and a review of EDP trends constructed in journals studied of this theme. Thus, the final part contains the result, suggestions, limitations, and suggestions for future research.

\section{Literature Review}

\section{Entrepreneurship Development Program (EDP)}

Entrepreneurship is considered a critical alternative strategy to deal with various situations, such as financial crises and increased unemployment rates (Galvão et al., 2018). It is appreciated as a trigger of regional prosperity and social development (Ashrafi et al., 2020; Galvão et al., 2019; Song \& Winkler, 2014). The entrepreneurship level of a country has been shown to influence the advancement of national economies (Atems \& Shand, 2018; Prieger et al., 2016), progress and innovation (Landström \& Harirchi, 2018; Sánchez, 2013), the number of job creation (Shane \& Venkataram, 2012), and the growth in nominal Gross Domestic Product (Khyareh et al., 2018). Therefore, due to the critical contribution to the 
economy's sustainable development, policymakers have been focused on shaping education and training to ensure entrepreneurship development. This program is vital for developing entrepreneurship as it is packaged with managerial, financial, vocational, and technical training. Suminar et al. (2021) added that the entrepreneurship development program (EDP) is the right strategy to scale up the level of innovation, creativity, ability, and literacy of entrepreneurs to produce new, profitable young entrepreneurs to create jobs and assist the government in alleviating unemployment and poverty. Many researchers have discussed various connotations and meanings of EDP that different direct approaches in its theoretical development. Such discussions are still going on, multiple researchers' Ahmad et al., (2018), Fayolle \& Gailly (2008), and Gibb (2002) stated that there is no complete consensus on definitional terminology. They claimed that the meaning of EDP can only be deduced from their emphasis and the objective of public policy 'initiatives. For example, Sudha (2019) argues that EDP improves entrepreneurial passion, competency, and capability to run enterprises. EDP also changes people's attitudes in developing their competency, passion, working capacity, and knowledge. Besides, EDP helps participants identify any business opportunities. It also boosts the confidence, reflection, expertise, and qualification to operate a successful business (Jones \& English, 2004; Kumar, 2017). Landra et al. (2018) explained that EDP are set up to train their entrepreneurial abilities and innovation. To summarize, numerous researchers (Béchard \& Denis, 2005; Béchard \& Denis, 1998; Gabrielsson et al., 2020; Heinonen \& Hytti, 2016; Interman, 1992; Kyrö, 2015; Lackéus, 2015) classified these education and training programs into simple three purposes. The purposes are to promote business awareness and creation, small business development, and train trainers.

\section{Entrepreneurship Development Programs (EDP) Evaluation}

The attention of EDP is booming worldwide. Although there is debate whether these programs should be introduced at an early age (elementary school) or university level, more and more public policy "initiatives" related to entrepreneurship are implemented by the government to accelerate the growth of business and enhance entrepreneurial spirit and literacies. (Fayolle, 2013) also added that given that it is a hot topic on the political agenda, there is an increasing number of publications by academicians that have focused on EDP. However, the critical question now arises, whether the implementation of EDP affects the intended goals and produces an effective result. (Brentnall et al., 2018) argued that if public money were allocated on such initiatives because they are represented as solutions to societal 
issues, it was reasonable to examine whether they were a good investment. Therefore, more investigations should be made in evaluating EDP (Farashah, 2013; Larso et al., 2018).

Surprisingly, despite the huge number of public initiatives allocated to this program (and the critical issue from government perspectives), a little study is available to comprehensively discuss the assessment and evaluation of EDP (Fayolle, 2013). Yet Acs et al. (2016) and Gustafsson-Pesonen \& Remes (2012) also pointed out that the review of the effectiveness of the EDP remains debatable. While the impact of the program or session on trainees, students, and other participants may be an appropriate evaluation criterion, there is still the issue of how to measure it. What should the indicators be, and how should they be measured? How can you quantify a shift in someone's intention or behavior? How may the sign of the time component be considered? And how can educational, teaching, and training aspects be distinguished from all other factors that influence the decision to pursue a particular career path or profession (Fayolle, 2013)?

The nature of EDP that is inseparable from training and education made the teaching model one of the critical sources in evaluating EDP. Eseryel (2002) identified six approaches that can be used in assessing EDP: goal-based evaluation, goal-free evaluation, responsive evaluation, systems evaluation, and professional review and quasi-legal. Fayolle (2013) added that among these approaches, goal-based (Kirkpatrick's reaction, learning, behavior, result framework) and systems-based approaches (such as Input, Process, Output, Outcome model by Bushnell) are predominantly used to assess EDP. EDP evaluation should focus more on the process than content (Gruenwald, 2014). Lundström et al. (2014) and Vesper \& Gartner (1997) also strengthened that argument by stating that the accomplishment of programs goals and teaching methods are the two most commonly used to assess EDP. Moreover, Galvão et al. (2019), Nyadu-Addo \& Mensah (2018) added that the attendances and participation in the business clinic (assessment), context (Galvão et al., 2018; Jessica \& Menold, 2015; Purzer et al., 2016), individual characteristics (Fretschner \& Weber, 2013; Huang-Saad et al., 2018), knowledge/theory understanding (Brentnall et al., 2018; Neergaard, 2014), as another EDP successful indicator. The program assessment offers information required for external certification and accountability information and delivers information used internally for quality control and improvement purposes (Lundström et al., 2014; Palomba \& Banta, 1999). 


\section{Methods}

This study used systematic literature reviews that cover EDP evaluation-related topics for program improvement. Armitage \& Keeble-Ramsay (2008) Borrego et al. (2014) and Tranfield et al. (2003) added that the SLR technique shows an important practical (in terms of accuracy for duplicability) when dealing with many investigations presented in a long period. SLRs are widely used for conducting evidence-based policy (Pittaway, 2016; Pittaway \& Cope, 2007). Therefore, considering these points, we utilize SLR to identify issues on EDP evaluation and analyze its growth. The analysis also intends to assess the impact of papers on this subject, analyze journals that produce documents, verify significant writers and academicians, and classify desirable topics and procedures.

The search was conducted using the Scopus database and covered the period 1989 to 2021. The terms used to determine relevant studies were examined in titles, abstracts, and keywords. These terms were entrepreneur*," "develop*," "evaluate*," and "education or training." The core logic to select the Scopus database was its extensive analysis of universally indexed papers of a value standard by academics. Furthermore, many papers recognized by Scopus are also accessible in other databases. As one of the most comprehensive databases, Scopus can also form a different bibliographic outcome than other databases. Because the research of EDP evaluation remains thin, we chose to use all articles about this topic in Scopus, from 1989-2021, to have a rich data source. To the best of our knowledge, there is no existing SLR that focuses on exploring the evaluations of the EDP from the Scopus database published from 1989 to 2021. From this search, it can be known that the first papers in the Scopus were written by Wan (1989) and Curran \& Stanworth. (1989) While Wan (1989) study focused on evaluating the type and efficacy of a company's workshop program to promote business planning competencies, Curran \& Stanworth (1989) assessed the character of entrepreneurship education. For our study, these two papers published in 1989 will be treated as the beginning point of the EDP evaluation discourse. Furthermore, we first selected documents with analytically confirmed information and eliminated documents other than journal articles to obtain the necessary papers. Then, we chose "entrepreneur*," "develop*," "evaluate*," and "education or training" as keywords to discover papers related to this theme. The resulting outcome was a total of 1191 papers. These papers then undergo four phases of elimination. First, we eliminated papers not written in English (reducing the article count from 1191 to 1132). Second, writings other than social, management, and business scope were eliminated, reducing the papers to 481. Third, we 
excluded other disciplines to focus just on the theme. Lastly, we stopped outcomes that were not a journal article or different than the theme. The final result used as the base for SLR is 366 papers. Table 1 presents a summary of the phase used in the SLR method.

Table 1. Literature Review Exclusion Criteria

\begin{tabular}{|c|c|c|}
\hline Stage & Exclusion Criteria & Amount \\
\hline Stage 1 & $\begin{array}{l}\text { Search Scopus bibliography by "entrepreneur*," } \\
\text { "develop*," "evaluate*," and "education or training" } \\
\text { keywords. }\end{array}$ & 1191 \\
\hline Stage 2 & Choosing outputs that were written in English. & 1132 \\
\hline Stage 3 & $\begin{array}{l}\text { Choosing output that focused on social, management, } \\
\text { and business scope. }\end{array}$ & 481 \\
\hline Stage 4 & $\begin{array}{l}\text { Choosing the scientific papers only, eliminate } \\
\text { conference papers and review. }\end{array}$ & 366 \\
\hline
\end{tabular}

Figure 1. Summary of SLR Process

\begin{tabular}{|c|c|c|c|c|}
\hline Protocol & $\begin{array}{l}\text { Search Database } \\
\text { Scopus }\end{array}$ & $\begin{array}{r}\text { S } \\
\text { "Entr } \\
\text { "Ev? }\end{array}$ & $\begin{array}{l}\text { Keywords } \\
\text { eur", "Develop", } \\
\text { ", "Education", } \\
\text { raining" }\end{array}$ & $\begin{array}{c}\text { Cover Periods } \\
1989-2021\end{array}$ \\
\hline & \multicolumn{4}{|c|}{$\downarrow$} \\
\hline Question & \multicolumn{4}{|c|}{ What is EDP evaluation? } \\
\hline Search & \multicolumn{4}{|c|}{$\begin{array}{c}\text { Exclusion Criteria } \\
\text { Subject area: Other than social, management, and business scope. } \\
\text { Language: Other than English. } \\
\text { Type: The scientific papers only, eliminate conference paper and } \\
\text { review }\end{array}$} \\
\hline Impact & \multicolumn{4}{|c|}{$\begin{array}{l}\text { Quality } \\
\text { Citation }\end{array}$} \\
\hline Framework & \multicolumn{4}{|c|}{$\begin{array}{c}\text { Classification System } \\
\text { Title, Authors, Citation, Country, Topic or Article, EDP Evaluation: } \\
\text { Typology of The Evaluation and EDP Antecedents }\end{array}$} \\
\hline Code & \multicolumn{4}{|c|}{$\begin{array}{l}\text { VOS Viewer } \\
\text { Co-citation }\end{array}$} \\
\hline $\begin{array}{l}\text { Insight and } \\
\text { Critique }\end{array}$ & \multicolumn{2}{|c|}{$\begin{array}{l}\text { What is EDP evaluation? } \\
\text { EDP evaluation typology }\end{array}$} & \multicolumn{2}{|c|}{$\begin{array}{l}\text { What are the factors that influence } \\
\text { the EDP result? } \\
\text { EDP antecedents }\end{array}$} \\
\hline $\begin{array}{l}\text { Future } \\
\text { research }\end{array}$ & \multicolumn{2}{|c|}{$\begin{array}{l}\text { Theory: EDP evaluation } \\
\text { model. }\end{array}$} & \multicolumn{2}{|c|}{$\begin{array}{l}\text { Contents: Research on the emerging } \\
\text { and developing countries. }\end{array}$} \\
\hline
\end{tabular}


The quality impact of the manuscript often refers to the number of citations. Although the usage of citation has been a debate for over decades (as the older the manuscript has had more time to accumulate citations), the usage of citation as the proxy of the quality of manuscript remained still (Dumay et al., 2014). Therefore, to overcome the bias, this study uses citation analysis into three points of view which are co-authors citations network analysis, co-citations sources network analysis, and co-citations and corresponding group analysis. The result of Tables 3 and 4 compare the top 10 authors and top 10 co-cited authors indicated that rather than a few authors dominating the rankings, the rankings show a wide range of authors; this reflects the breadth and diversity of scholars and institutions working in this field (Demartini \& Beretta, 2020; Massaro et al., 2016). Furthermore, the analytical framework and dataset (text queries) must be defined and coded using the developed framework as another phase of SLR (Massaro et al., 2016). Following the coding process, we completed the final phase of the SLR, which involves analyzing the results to produce insights and critiques, respond to the research question, and make recommendations for future research directions. Figure 1 shows the summary of the SLR process used in the study.

\section{Result and Discussion}

\section{Entrepreneurship Development Programs (EDP) Research Trends}

Figure 2. Number of Publications (EDP related) per Year

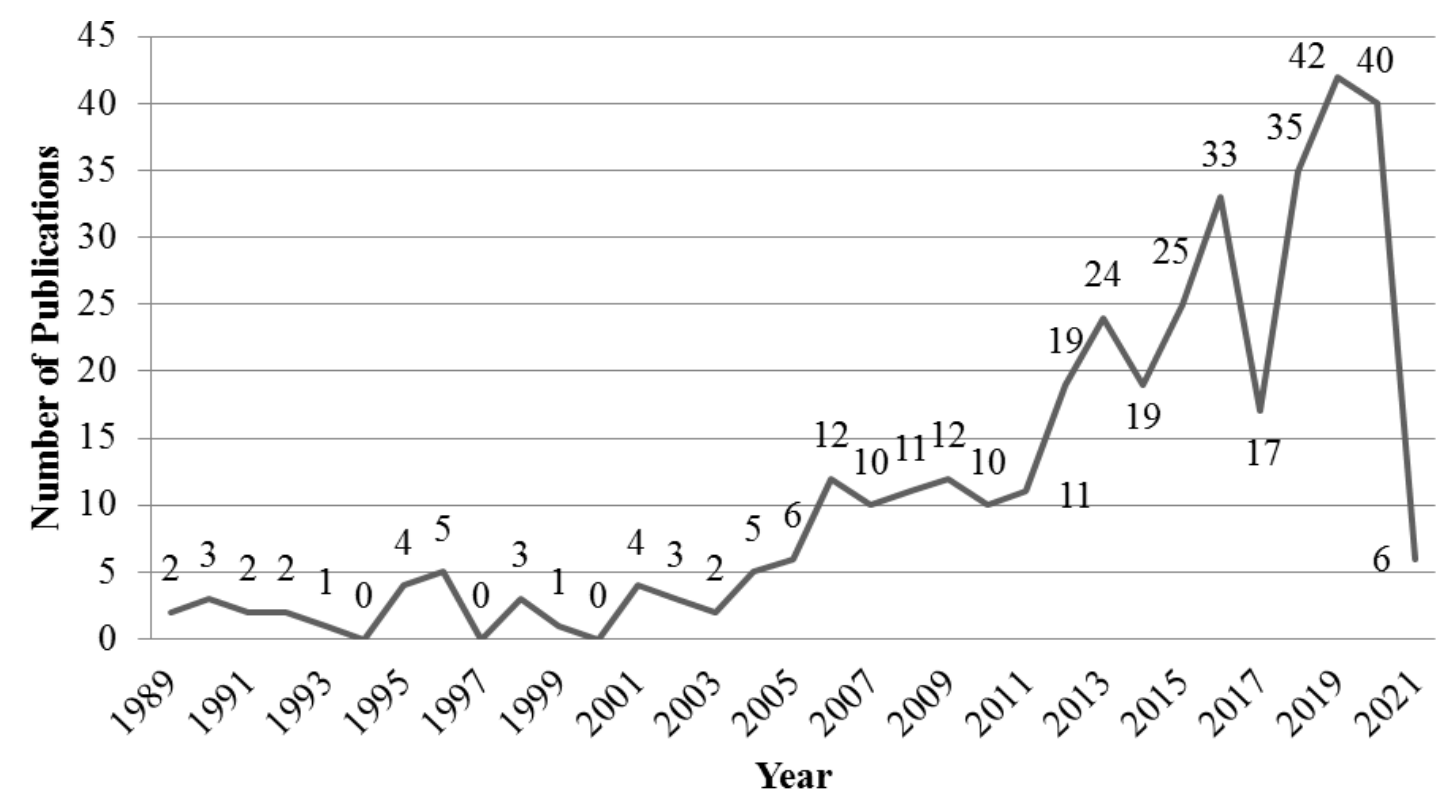

Figure 1 shows the development of published researches on the topic of EDP evaluation. In 2001, the subject started to appear at a constant level, whereas some periods before this year had no papers. Between fourteen years (1989-2003), there were only 29 papers 
published concerning EDP evaluation. The amount started to rise dramatically since 2004, with the largest amount of published research being 42 papers in the year 2019. At the beginning of 1989, the EDP study has focused on the program characteristics identification and their target participants. Furthermore, the program improvement is made based on the program's evaluation. Wan (1989) explores the characters and effectiveness of the enterprise training program. The Australian government founded this in 1989 to promote business planning competency. All training programs are held in the capital city of each state of Australia and are divided into three phases: seminar series, intensive training, and business plan competition. Thus, these programs were evaluated by past participants' perception of the program effectiveness, economic (monetary) impact, and feedback evaluation from sources other than participants (employers and academicians). He found that the training program has effectively achieved the program's goals to promote business planning competency. The evaluation of these enterprise's workshop results is that these programs lack focus on personal training qualities, as they over-emphasize practical skills in business planning. Following Wan (1989) and Curran \& Stanworth (1989), the study concerned four typologies of entrepreneurial education: entrepreneurial education for small businesses, entrepreneurial awareness for entrepreneurs, advancing industry for small business owners, and small business awareness. They evaluate that the program with the highest effectiveness was small business education for small business owners.

Figure 3. Publications Based on Countries and Continents
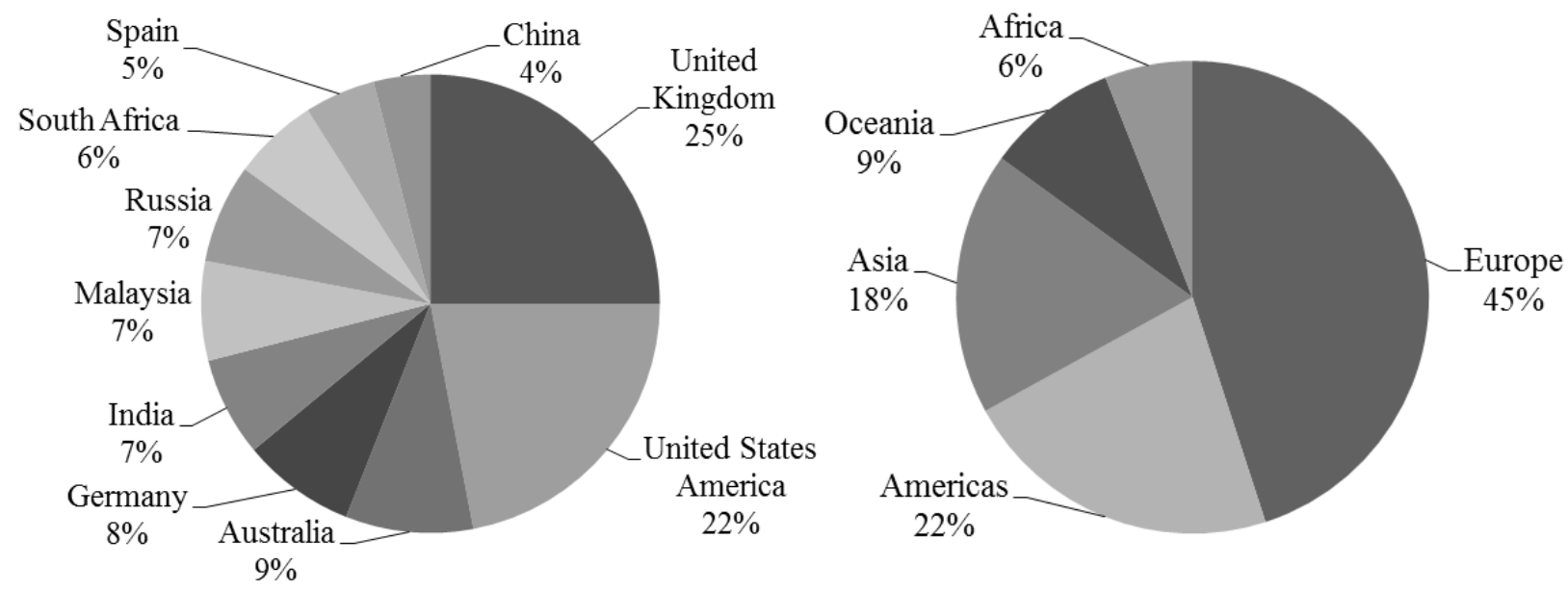

Figure 2 confirms that the United Kingdom (64 manuscripts), United States America (56 manuscripts), Australia (23 manuscripts) is the most contributors of EDP-related studies in cumulative with the contribution of more than 50\%. Europe accounted for the biggest continent contributors of the study related to EDP with a contribution of $45 \%$ followed by 
America, Asia, Oceania, and Africa. Table 2 presents the top five publishers of 160 journals that discuss this issue. In addition, this topic began to come up in 1990 in the Journal of Business Venturing. The subject area of management, business, and education appears the most in the top-five publishers.

Table 2. Top Five Publishers

\begin{tabular}{|c|c|c|c|c|c|}
\hline Journals & $\begin{array}{l}\text { Number of } \\
\text { Articles }\end{array}$ & $\begin{array}{c}\text { First } \\
\text { Published }\end{array}$ & $\begin{array}{c}\text { Number of } \\
\text { Citations }\end{array}$ & $\begin{array}{l}\text { SJR } \\
\text { SNIP }\end{array}$ & $\begin{array}{l}\text { Subject } \\
\text { Area }\end{array}$ \\
\hline $\begin{array}{l}\text { Education and } \\
\text { Training }\end{array}$ & 34 & 2005 & 965 & $\begin{array}{l}0.752 \\
1.504\end{array}$ & $\begin{array}{c}\text { Bs, } \mathrm{Mg}, \mathrm{Ac}, \\
\mathrm{Ed}\end{array}$ \\
\hline $\begin{array}{l}\text { Journal of } \\
\text { Entrepreneurship } \\
\text { Education }\end{array}$ & 29 & 2011 & 141 & $\begin{array}{l}0.283 \\
1.030\end{array}$ & $\begin{array}{c}\text { Ac, Bs, Mg, } \\
\text { Ed, Ec, Et }\end{array}$ \\
\hline $\begin{array}{l}\text { Industry and Higher } \\
\text { Education }\end{array}$ & 18 & 1998 & 196 & $\begin{array}{l}0.450 \\
0.718\end{array}$ & $\mathrm{Bs}, \mathrm{Mg}$, Ed \\
\hline $\begin{array}{l}\text { Journal of Business } \\
\text { Venturing }\end{array}$ & 12 & 1990 & 2867 & $\begin{array}{l}4.977 \\
3.700\end{array}$ & $\mathrm{Bs}, \mathrm{Mg}$ \\
\hline $\begin{array}{l}\text { Emerald Emerging } \\
\text { Markets Case Studies }\end{array}$ & 11 & 2013 & 0 & $\begin{array}{l}0.166 \\
0.048\end{array}$ & $\begin{array}{c}\mathrm{Bs}, \mathrm{Mg}, \mathrm{Ed}, \\
\mathrm{St}\end{array}$ \\
\hline
\end{tabular}

Note: Ac= Accounting, Bs=Business, Ed=Education, Ec=Economics, Et=Econometric, $\mathrm{Mg}=$ Management, $\mathrm{St}=$ Strategic

Table 3. Top Ten Authors Based on Number of Publications

\begin{tabular}{lccc}
\hline Authors & $\begin{array}{c}\text { Number of } \\
\text { Publications }\end{array}$ & $\begin{array}{c}\text { Total } \\
\text { Citations }\end{array}$ & $\begin{array}{c}\text { Average } \\
\text { Citations }\end{array}$ \\
\hline Jones, Paul & 4 & 66 & 16.5 \\
Baptista, Rui & 3 & 35 & 11.6 \\
Frese, Michael & 3 & 127 & 42.3 \\
Januario, Carlos & 3 & 26 & 8.7 \\
Maritz, Alex & 3 & 25 & 8.7 \\
McElwee & 3 & 33 & 11 \\
Naia, Ana & 3 & 35 & 11.7 \\
Trigo, Virginia & 3 & 35 & 11.7 \\
Abdullah, Moha Asri & 2 & 2 & 1 \\
Balan, Peter & 2 & 27 & 13.5 \\
\hline
\end{tabular}

While co-author in this study is defined as one or more persons who write the article, cocitations are the frequency in which two documents are cited together by other documents. Table 3 highlighted the most performed authors in the current time and the number of their 
citations. Even though Jones issued the most publications related to EDP (4 publications), it was Fayolle that has the most cited of publications (563 citations) followed by Hornsby and Palich (506 and 488 citations).

Table 4. Top Ten Co-Citations Authors

\begin{tabular}{lccc}
\hline Authors & $\begin{array}{c}\text { Number of } \\
\text { Publications }\end{array}$ & $\begin{array}{c}\text { Total } \\
\text { Citations }\end{array}$ & $\begin{array}{c}\text { Average } \\
\text { Citations }\end{array}$ \\
\hline Fayolle, Alain & 173 & 563 & 3.3 \\
Hornsby, Jeffrey & 46 & 506 & 11.0 \\
Palich, Leslie. & 22 & 488 & 22.2 \\
Fischer Eileen & 71 & 483 & 6.8 \\
Chandler, G. N., & 24 & 445 & 18.5 \\
Linan, Fransisco & 59 & 283 & 4.8 \\
Zacharakis, Andrew & 34 & 273 & 8.0 \\
Fiet, James & 33 & 269 & 8.2 \\
Gurol, Yonca & 4 & 207 & 51.8 \\
Heinonen, Jarna & 28 & 183 & 6.5 \\
\hline
\end{tabular}

\section{The Citation Network Analysis}

The Citation Network Analysis (CNA) is based on the list of references found in journal articles or other types of publications. References are citations to prior works that have influenced the direction of a study. Even though papers with a large number of citations are not necessarily representative of influential and world-class research, it is widely accepted that citations can be used to assess the relevance of publications (Colicchia et al., 2018; Dawson et al., 2014). Papers may be removed from the study if no other works cite them, regardless of their content's importance, or if they have garnered a small number of citations due to their recent publication. Other technologies, like keyword analysis and citation score analysis, might thus complement and minimize the aforementioned flaws. Therefore, to build bibliographic networks, a VOS viewer was used to analyze bibliometric networks and cluster analysis. Figure 3 presents the co-author's network analysis based on (at least) 20 co-citations per author, demonstrating the "world" of five groups of the most outstanding co-authors of 106 authors. Although these authors discuss a diverse range of topics, they cite one another quite frequently. It signifies the presence of a solid network (correlation) between them. It also can be acknowledged that the EDP study is growing by citing each other's papers. Furthermore, Figure 4 that was formed with at least 20 co-citations per journal shows that 
most of the journals - out of 78- with co-citations were issued in the recent periods and polarized into the six biggest connected groups. The top three journals that published EDP frequently are The Journal of Business Venturing, Entrepreneurship Theory and Practice, and Journal of Small Business and Management. There is a link between groups, indicating the interconnection among them.

Figure 4. Authors Citations Network Analysis (Authors Perspective)

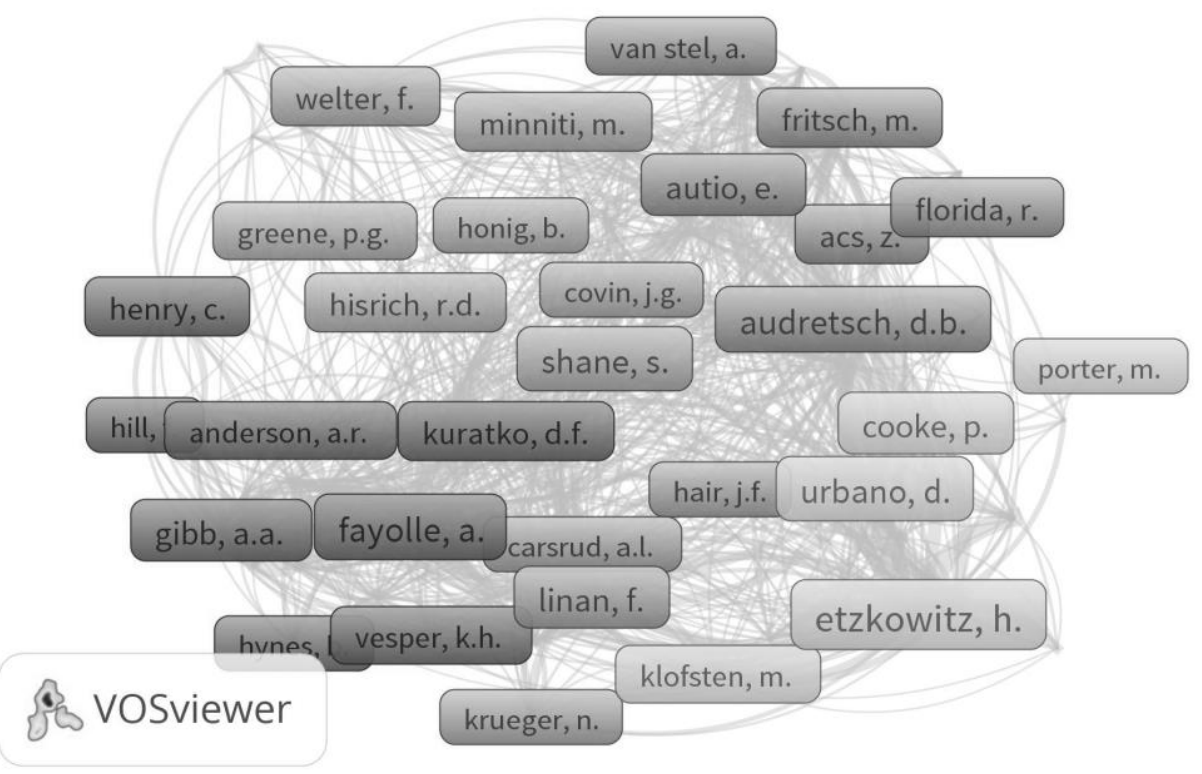

Figure 5. Co-Citations Network Analysis (Sources of Publication Perspective)

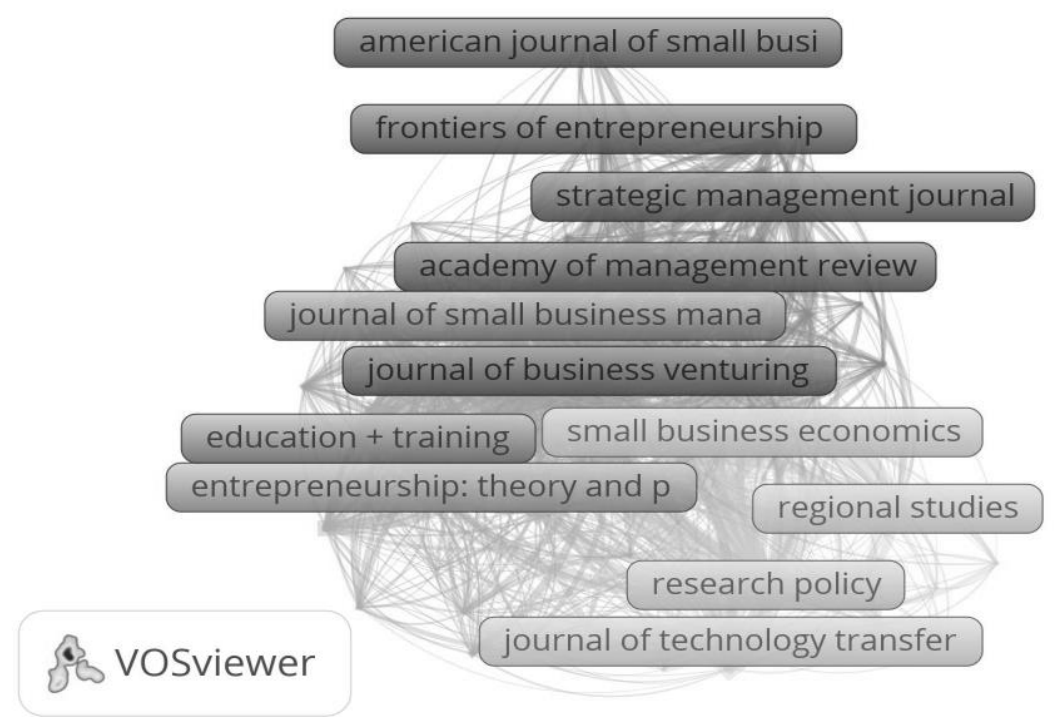

For further analysis with at least four co-citations per manuscript, 80 most of the co-cited manuscripts were carefully chosen and classified into 5 segmented groups. These 5 groups selected are Group 1 that includes 30 percent of the journals and Group 2 Group 5 which has 
17.5 percent respectively. Figure 5 proved that these five groups have a strong connection to each other.

Figure 6. Co-Citations and Corresponding Group Network Analysis

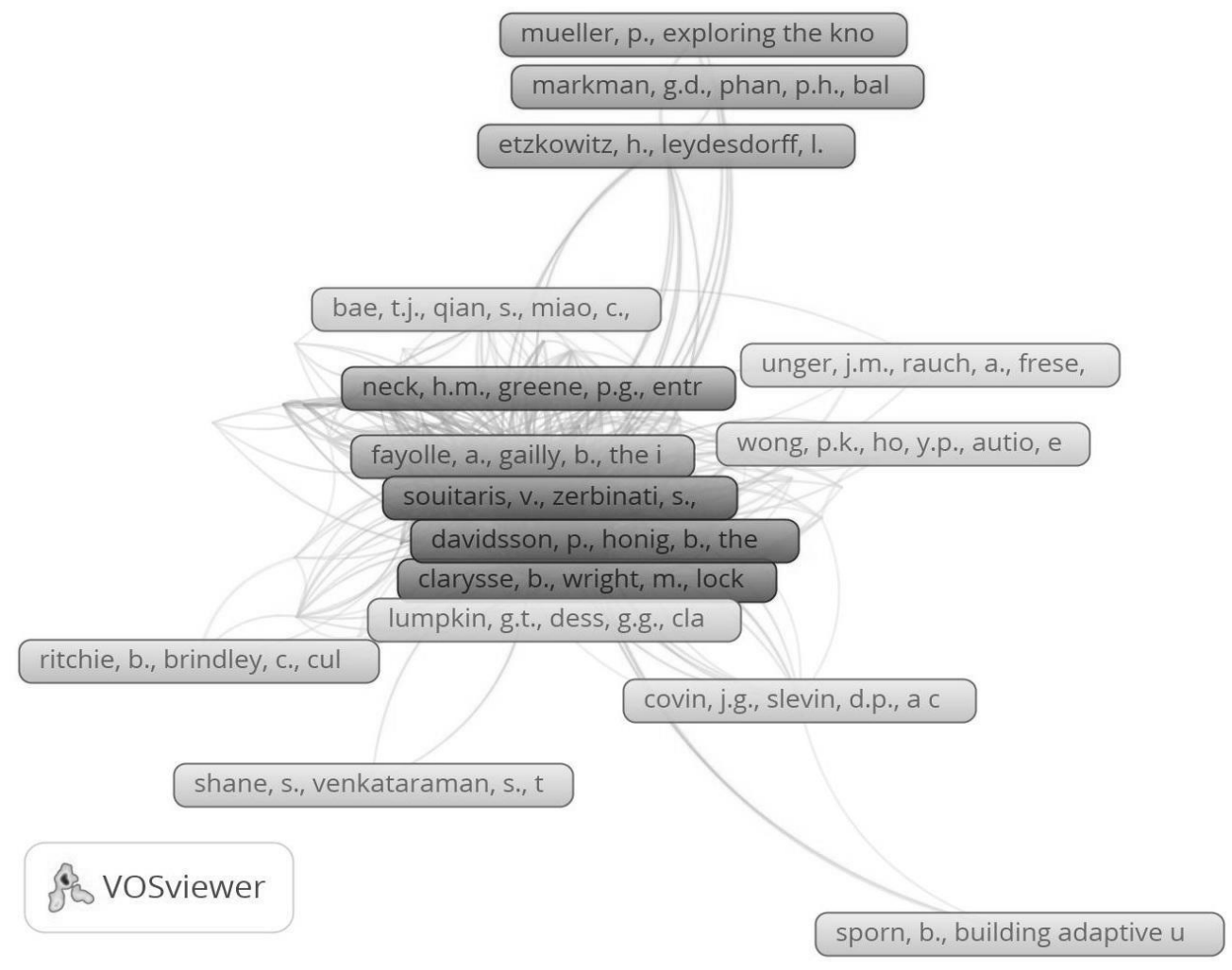

\section{Group 1}

This group consists of 30 lists of the manuscript, with 8 of them having more than four co-citations. The authors in Group 1 evaluated the EDP based on the impact and process. (Kolvereid \& Moen, 1997; Matlay, 2008; Matlay et al., 2009; Souitaris et al., 2007) evaluated the program based on the impact, while Jones did the evaluation based on the process. Matlay (2008) evaluated the impact of the EDP on the entrepreneurial result of the graduates of Higher Education Institutions. He found the entrepreneurial education improves these graduates with sufficient literacy and competency to enter both an entrepreneurial profession and their careers - after one year, five years, and ten years. The results of this ten-yearentrepreneurship-education evaluation show that the program has a successful entrepreneurial outcome. The majority of participants experience fast progression on owning a small business or obtaining impressive management levels. Meanwhile, Souitaris et al. (2007) evaluated the entrepreneurship program's result to the entrepreneurial mindset and motive of 250 science and engineering undergraduates from two campuses in London and Grenoble. Their analysis confirms that entrepreneurship programs increase some 
entrepreneurial mindset and reason. Besides, the most significant benefits come from a program framework that incorporates an emotional component. The results contribute to the planned behavior theories and education theories. The findings also have broader inferences for the entrepreneurial emotion philosophy and for teaching entrepreneurship practices. Next, Kolvereid \& Moen (1997) evaluated the impact of entrepreneurship education on business graduates with a major in entrepreneurship versus graduates in other majors in a Norwegian business school. They found that graduates with a major in entrepreneurship have a bigger entrepreneurial motive. Lastly, Matlay et al. (2009) that evaluated the EDP in 1995-2004, found that EDP in the United Kingdom HEI positively impact the graduate's mindset towards their career and promote the potential entrepreneurs requiring expertise and competency in starting, running, and growing their business (Matlay \& Carey, 2007). They found that, in 2000, the regional government funding and cultural issues were perceived as a barrier for EDP. In 2004, they discovered that all the 40 campuses in the samples establish Entrepreneurship education because of the demand from students, faculty staff affiliates, and government support funding.

Katz (2003) who analyzed more than 100 publications of the Entrepreneurship Education in America from 1876 until 1999, found that the cited authors formed an outline to define the chronology of entrepreneurship education in America. This framework is beneficial as a guide for future research. In addition, Jones's study provides an exclusive technique of understanding the learning process to be entrepreneurial in university (Jones, 2010). Based on the research findings, the author argues that the students in the university understand the limitation of entrepreneurship education they learn. Consequently, the educators should consider the students' capacity to provide a better learning atmosphere to develop the students' capability. Understanding the limitations of both educator and student is crucial to maximizing the entrepreneurship program in the university. The EDP could be evaluated based on two aspects: the participants and their business. The evaluation based on participants could be determined from the development of knowledge of entrepreneurship theory; the essential of entrepreneurship; the significance of entrepreneurship; creative and innovation competency; entrepreneurial and ethical self-evaluation; and interacting, selling, and negotiation. In addition, the business developments are dependent on their business changes: finding and estimating chances; monetary of a concept; constructing opening strategies; developing a business planning; getting capital; opening the enterprises; growing the enterprise; and harvesting plan. The program characteristic and the delivery of the EDP are also discussed in this group as Fiet (2000a, 2000b) argues that the teaching process should 
not be dull, as the most effective programs for coaching theory are connected to definite persons, places, timing, contacts, and environments.

\section{Group 2}

This group consists of 14 list manuscripts with seven of them having more than four cocitations, emphasizing four topics which are program evaluations, program characteristics, program stakeholders, and challenges. The authors in this group evaluated EDP based on the impact and process. The first publication assessed the influence of the Entrepreneurship Education Program on the students' entrepreneurial intention. They found that the program had an extremely low positive effect on their recognized behavioral controls (Fayolle, A., Gailly B., 2006). The second paper proposes a model of entrepreneurship education majority stimulated by education sciences. Also, this publication analyses the ontological and educational of the program. Fayolle \& Gailly (2008) used the proposed framework to review several categories of entrepreneurship education programs, concentrating on three main types of education processes. Moreover, Duval-couetil (2013) discussed the approach of the EDP evaluation. She argued that the impact evaluation should be determined by the stakeholder consensus, considering the diverse range of internal and external collaborators with different interests in the educational program. This SLR also focused on the program challenges. The challenges especially relate to entrepreneurship education program valuation. Moreover, she promoted the stakeholders' involvement and consensus on developing, implementing, and evaluating entrepreneurship education programs. She also proposed to involve comprehensive stakeholders. The evaluation requires many resources: time, money, and expertise. Also, participation from expert evaluators is essential. She offered three assessment instruments of entrepreneurship education: evaluation on the course-level that appraises the participants' reaction to an entrepreneurship program; assessment on the broader agenda that measures a wider array of results, including interest, expertise, response, career decision, business creation, financial impact; and evaluation on specific parts or ideas related to entrepreneurship. Meanwhile, Rauch \& Hulsink (2015) have tested the effectiveness of entrepreneurship education. They evaluated the program impact based on the planned behavior theory. Then, Martin, et al. (2013) reported a meta-analysis of the formulation of human resources in entrepreneurship. They found a significant impact of entrepreneurship education and training on human resources and entrepreneurship outcomes. Also, they observed that the entrepreneurship outcome is stronger for entrepreneurship education programs than entrepreneurship training programs. 
Furthermore, the topic of program characteristics was discussed by Fayolle \& Gailly (2008). There are three categories of entrepreneurship programs namely learning to be enterprising persons, learning to be competent entrepreneurs, studying to be academicians (teachers or researchers in the field of entrepreneurship). Another study from Gibb (2002) and Gorman et al. (1997) even added that as the rising of entrepreneurship interest is mainly due to the pressure of globalization, the need for entrepreneurial behavior is being felt by a broad variety of stakeholders (e.g., pastors, medics, educators, communities, and others) with a concern on the market.

\section{Group 3}

This group consists of 14 list manuscripts that emphasize the program characteristics such as content program (Detienne \& Chandler, 2004; Edelman et al., 2008; Fiet, 2000b). The first paper studied by Solomon (2007) presented an analytical synopsis of contemporary entrepreneurship education in the USA in 2004-2005. The second article was the research of Shane \& Venkataraman (2000) that conceptualized the agenda of the Entrepreneurship study. Detienne \& Chandler (2004) discussed opportunity identification as a crucial subject in the entrepreneurship program. They appreciated opportunity identification as a core content of entrepreneurship education, which can be advanced as exclusive skills. The participants can learn the competency through the Solomon Four Group Designed experiment. Moreover, while Edelman et al. (2008) found that there are some intersections and differences between the real-life of start-ups to the textbook content, Fiet (2000a, 2000b) in his articles, reviewed several assumptions that teaching theories to students have a more significant impact than only showing them what entrepreneurs do. He also explored the content of entrepreneurship education and the process of the program actualization.

\section{Group 4}

This group is composed of 14 manuscripts that emphasize the EDP evaluation and context. It contains five publications with more than three co-citations with the most of them concurs that EDP evaluation should be carried out based on the impact (Karlan \& Valdivia, 2011; Krueger et al., 2000; Oosterbeek et al., 2010). While Ajzen (1991) analyzed the Theory of Planned Behavior in EDP evaluation, Oosterbeek et al. (2010) evaluated the impact of an entrepreneurship education program on university scholars' competency and enthusiasm. However, the latter found that the program did not achieve the expected effect. In 2011, Karlan \& Valdivia (2011) evaluated the impact of training on microfinance customers and organizations. Also, Krueger et al. (2000) contrasted two intention-based schemes with their capacity for the entrepreneurial intention estimation. The models are based on the Planned 
Behaviour Theory of Ajzen (1991) and the entrepreneurial event model of Shapero. They proposed that the prediction model should depend on the intention because situational or individual determinants have a low prediction ability based on the empiric cases. Finally, Thomas \& Mueller (2000) investigated culture or the connection among philosophy on four personality traits that are linked with entrepreneurial passion. The personal entrepreneurial characteristics are innovation, locus of control, risk-taking, and energy.

\section{Group 5}

This group contains 14 manuscripts that emphasize EDP evaluation, characteristics, and challenges. Similar to the previous group, most of the manuscripts in this group concurs that EDP evaluation can be and should be conducted based on the impacts (Athayde, 2009; Fayolle \& Gailiy, 2015; Graevenitz \& Weber, 2009; Liñán et al., 2011; Nabi et al., 2017). On the first topic, Fayolle \& Gailiy (2015) recommended the framework of entrepreneurial intention and its antecedents to evaluate the impact of the EDP. Thus, the second study of EDP evaluation by Nabi et al. (2017) found that the research of the EDP (education) impact still mainly emphasizes short-term measures with impact index based on the emotion-based methods and the intention-to-behavior change. Moreover, while Graevenitz \& Weber (2009) proposed a theoretical framework of Bayesian learning to evaluate the improvement skills of entrepreneurship as the impact of entrepreneurship education, Athayde (2009) assessed the impact of the young entrepreneurship program on the participants. Lastly, Liñán et al. (2011) proposed the elements forming an entrepreneurial intention. They stated that personal characters and perceived behavioral control are the determinants of entrepreneurial intention.

The second topic is program characteristics. Kuratko (2005) and Pittaway \& Cope (2007) studied the contents of EDP which is the contents of market entry, compromise skills, leadership, construction skills, creative problem solving, and skills to use technology and innovation skills, intention to be entrepreneurs, business capital, copyright, risk management, characters of an entrepreneur, and growth constrain. The entrepreneurship education contents are established based on the real-life situation: business strategy, creating business for scholars, discussion with industrialists, situation investigation, and case study.

Thirdly, the program challenges topic. Kuratko (2005) divided the challenges of entrepreneurship study into ten issues namely stagnation, low quality of publications, lack of academician experts in entrepreneurship, low level of technology usage, the dot-com tradition, conflicting of academia with the real-life, the dilution of entrepreneurship, managing the risk, the leadership revolving of academic administrative, and the one-man show. Therefore, to overcome the challenges in promoting entrepreneurship programs, the 
usage of robust theoretical and conceptual basics combine with a real investigation (not take it for granted) is a mandatory act (Fayolle, 2013).

\section{Discussion}

The descriptive of EDP issue from the five selected groups above is mostly concerned with program evaluation, characteristics, challenges, stakeholders, and context. In addition, the topic of program evaluation and program characteristics are recognized as the main significant them of EDP evaluation (See Table 5). In addition, the findings show that most evaluations are conducted based on the impact of the program. Just a few of the papers consider the process of EDP as the assessment of the EDP implementation.

Table 5. EDP Issues

\begin{tabular}{lccccc}
\hline Group & Evaluation & Characteristics & Challenges & Stakeholders & Context \\
\hline 1 & $\sqrt{ }$ & $\sqrt{ }$ & $\sqrt{ }$ & \\
2 & $\sqrt{ }$ & $\sqrt{ }$ & & \\
3 & & $\sqrt{ }$ & & \\
4 & $\sqrt{ }$ & $\sqrt{ }$ & $\sqrt{ }$ & \\
5 & $\sqrt{ }$ & $\sqrt{ }$ & & \\
\hline
\end{tabular}

Table 5 above illustrates the five topics of co-authors in the EDP-related studies. From the existing papers, several topics are discussed, with some of them revealing similarities. The most significant issues are program evaluations and program characteristics, found in four groups. Firstly, EDP can be evaluated based on impacts and processes (although most of the assessments also assess the implications to assess the program achievement). To appraise the result of the program is necessary, but to assume by its impact alone is significantly insufficient, as the goal of the review is to improve the program. The findings above also reveal that a few articles review the process. Nevertheless, since two other minority authors use the process as a basis of a program evaluation, it can be considered as rebalancing the program evaluation and identifying current and future trends.

There were five topics discussed in the literature. The first topic was the EDP evaluation. The literature on EDP evaluation reveals that EDP evaluations are primarily concerned with the impact of the program on the participants' capabilities and their business. Nevertheless, just a few of the bibliography suggested for review on the EDP implementation process, such as the delivery process, the expertise of stakeholders involved, and other aspects of the implementation process. Even though most previous research conducted the EDP evaluation 
based on the impact, this study expands the scope for EDP evaluation based on both effect and the process. The aim to evaluate the impact is to find whether the intended goals are achieved or not. Besides, the objectives of the review of the operation of the EDP are to find out the quality of the process and improvement purposes. The findings conclude the assessment typology based on both the impact to see the result and the process that consist of the evaluation of the impact and process, the evaluation of the impact, and the evaluation of the process. However, since the EDP evaluation is complex due to the variety of the content, purpose, and approach (Fayolle \& Gailiy, 2015), the EDP evaluation should be conducted to ensure the program enhancement (Warhuus et al., 2017). This EDP evaluation and implementation need the participation of various stakeholders who have resources of expertise, money, and information (Bischoff et al., 2018; Duval-couetil, 2013) in short, medium, and long-term periods of evaluation (Galvão et al., 2019; Matlay, 2011). While numerous researchers evaluated the EDP based on the impact to measure the effectivity, nevertheless the evaluation of the process of the execution was also needed to ensure improvements of the future EDP. Consequently, it is suggested to evaluate EDP based on the impact and the process of the EDP.

The second topic discusses three program characteristics: program delivery, design programs, and program content. Thirdly, the discussion is about challenges, namely the program implementation, the challenge to understand the program, and the challenge of evaluating. Since the sources of the program come from the activity of attention of various stakeholders, then the success level depends on the stakeholder's participation level (Galvão et al., 2017). The fourth issue is the stakeholder. Bischoff et al. (2018) declared that stakeholder theory in a business context commonly refers to the organizations and individuals who can influence or be influenced by business activities. There are more than ten stakeholder categories that were defined by Leonidou et al. (2020) which consists of academia, government, community, customers, service intermediaries, user community, suppliers, business networks, start-up teams, innovation intermediaries, social media, university peers, NGOs, industry cluster, associations, friend and family. However, these wider ranges of stakeholders have often produced contra-productive conflict between each other due to the different systems and interests of each stakeholder. Some authors use Quadruple Helix (Dhewanto et al., 2021; Primanto et al., 2018), the Penta Helix (Tonkovic et al., 2015), collaboration, and the individual actors' model (Rustiadi \& Arina, 2019) as a framework to analyze the roles that stakeholders. Finally, the last issue of EDP evaluation in this study is the context, which means the diversity of programs. 


\section{Conclusion and Suggestion}

In this literature review, we have investigated 366 EDP manuscript related and explored several issues such as program evaluation, characteristics, challenges, stakeholders, and context, with program evaluation and characteristics. This study shows that most manuscripts that conducted EDP evaluations are based on the program's impact on the participants' competency, their businesses, or their career. While a few that the review of the process of EDP as the success criterion of EDP implementation. This study helps to identify EDP evaluation criteria based on their impact and process so it can produce a more comprehensive evaluation to improve EDP implementation. From a practical perspective, this study shows the policymaker the benefits of EDP evaluation. Other EDP studies may also be inspired to conduct EDP evaluation to make the program more effective and efficient. In summary, to accomplish the goal effectively and efficiently, there should be an evaluation of the goal's achievement and the antecedents.

The limitation of this study is the use of the Scopus database by excluding some papers in which involves subjectivity in grouping the articles and choosing the keywords. Future research could include Web of Science bibliographies, books, book chapters, and conference papers as sources. Future studies could also be an investigation on the evolution of the EDP implementation and evaluation during 1947-1989. It would also be compelling to discuss the conduct of the evaluation of EDP within Asia, Australia, and Africa contexts. Furthermore, future studies should also consider the need to explore, reflect, and ask questions more critically, not on the side of being taken for granted. For instance, by asking again, how could a program improvement be accomplished with a thorough evaluation? Considering the available resources are very limited, how do we do the evaluation? Is there any other benefit besides study, insight, and talent? Are there any differences between trainers with a practical background to the academician one? Do innovative ideas lead to wealth creation? Do the program significantly influence the business performance?

\section{References}

Acs, Z., Åstebro, T., Audretsch, D., \& Robinson, D. T. (2016). Public policy to promote entrepreneurship: a call to arms. Small Business Economics, 47(1), 35-51. https://doi.org/10.1007/s11187-016-9712-2

Ahmad, S. Z., Abu Bakar, A. R., \& Ahmad, N. (2018). An evaluation of teaching methods of entrepreneurship in hospitality and tourism programs. International Journal of Management Education, 16(1), 14-25. https://doi.org/10.1016/j.ijme.2017.11.002 
Ajzen. (1991). The Theory of Planned Behavior. Organizational Behavior and Human Decision Process, 50, 179-211.

Alvesson, M., \& Sandberg, J. (2011). Generating Research Questions Trough Probematization. Academy of Management Review, 36(2), 247-271.

Armitage, A., \& Keeble-Ramsay, D. (2008). Undertaking a Structured Literature Review or Structuring a Literature Review: Tales from the Field. The Electronic Journal of Business Research Methods, 6(2), 103-114. www.ejbrm.com

Ashrafi, D. M., Sarker, M. A. R., Hashim, J. B., Haque, A., \& Nayan, F. K. (2020). An exploration of the youths perception toward social entrepreneurship development: Evidence from Bangladesh. JEMA: Jurnal Ilmiah Bidang Akuntansi Dan Manajemen, 17(1), 88. http://dx.doi.org/10.31106/jema.v17i1.5539

Atems, B., \& Shand, G. (2018). An empirical analysis of the relationship between entrepreneurship and income inequality. Small Business Economics, 51(4), 905-922. https://doi.org/10.1007/s11187-017-9984-1

Athayde, R. (2009). Measuring Enterprise Potential in Young People. Entrepreneurship Theory and Practice, 33(2), 481-500.

Bae, T. J., Qian, S., Miao, C., \& Fiet, J. O. (2014). The Relationship Between Entrepreneurship Education and Entrepreneurial Intentions: A Meta-Analytic Review. Entrepreneurship: Theory and Practice, 38(2), 217-254. https://doi.org/10.1111/etap.12095

Béchard, J.-P., \& Denis, G. (1998). Entrepreneurship Education Research Revisited: The Case of Higher Education. Academy of Management Learning \& Education, 4(1), 2243.

Béchard, J., \& Denis G. (2005). Entrepreneurship Education Research Revisited: The Case of Higher Education. Academy of Management Learning \& Education, 4(1), 22-43.

Bischoff, K., Volkmann, C. K., \& Audretsch, D. B. (2018). Stakeholder collaboration in entrepreneurship education: an analysis of the entrepreneurial ecosystems of European higher educational institutions. Journal of Technology Transfer, 43(1), 20-46. https://doi.org/10.1007/s10961-017-9581-0

Borrego, M., Foster, M. J., \& Froyd, J. E. (2014). Systematic literature reviews in engineering education and other developing interdisciplinary fields. Journal of Engineering Education, 103(1), 45-76. https://doi.org/10.1002/jee.20038

Brentnall, C., Rodríguez, I. D., \& Culkin, N. (2018). The contribution of realist evaluation to critical analysis of the effectiveness of entrepreneurship education competitions. 
Evaluations of an entrepreneurship development program: A systematic literature review by Ronal Ferdilan, Wawan Dhewanto, Sonny Rustiadi

Industry and Higher Education, 32(6), 405-417. https://doi.org/10.1177/0950422218807499

Colicchia, C., Creazza, A., \& Strozzi, F. (2018). Citation network analysis for supporting continuous improvement in Higher Education. Studies in Higher Education, 43(9), 1637-1653. https://doi.org/10.1080/03075079.2016.1276550

Curran, J. \& Stanworth, J. (1989). Education and Training for Enterprise Problems of Classification, Evaluation, Policy and Research. International Small Business Journal, 7(2), 11-22.

Dawson, S., Gašević, D., Siemens, G., \& Joksimovic, S. (2014, March). Current state and future trends: A citation network analysis of the learning analytics field. In Proceedings of the fourth international conference on learning analytics and knowledge (pp. 231240). https://doi.org/10.1145/2567574.2567585

Decker, R., Haltiwanger, J., Jarmin, R., \& Miranda, J. (2014). The role of entrepreneurship in us job creation and economic dynamism. In Journal of Economic Perspectives (Vol. 28, Issue 3, pp. 3-24). American Economic Association. https://doi.org/10.1257/jep.28.3.3

Demartini, M. C., \& Beretta, V. (2020). Intellectual capital and SMEs' performance: A structured literature review. Journal of Small Business Management, 58(2), 288-332. https://doi.org/10.1080/00472778.2019.1659680

Detienne, D. R., \& Chandler, G. N. (2004). Opportunity Identification and Its Role in the Entrepreneurial Classroom: A Pedagogical Approach and Empirical Test. Academy of Management Learning and Education, 3(3), 242-257.

Dhewanto, W., Herliana, S., Yunita, F., Nur Rizqi, V., \& Williamson, I. O. (2021). Quadruple Helix Approach to Achieve International Product Quality for Indonesian Food SMEs. Journal of the Knowledge Economy, 12(2), 452-469. https://doi.org/10.1007/s13132-020-00644-2

Dumay, J. (2014). Reflections on interdisciplinary accounting research: the state of the art of intellectual capital. Accounting, Auditing \& Accountability Journal, 27(8), 1257-1264. https://doi.org/10.1108/AAAJ-05-2014-1714

Duval-couetil, N. (2013). Programs : Challenges and Approaches. Journal of Small Business Management, 51(3), 394-4019. https://doi.org/10.1111/jsbm.12024

Dvouletý, O. (2017). Effects of soft loans and credit guarantees on performance of supported firms: Evidence from the Czech Public Programme START. Sustainability (Switzerland), 9(12). https://doi.org/10.3390/su9122293 
Edelman, L. F., Manolova, T. S., \& Brush, C. G. (2008). Entrepreneurship Education: Correspondence between Practices of Nascent Entrepreneurs and Textbook Prescriptions for Success. Academy of Management Learning \& Education, 7(1), 5670 .

Eseryel, D. (2002). Approaches to Evaluation of Training: Theory \& Practice. Educational Technology \& Society, 5(2), 93-98.

Farashah, A. D. (2013). The process of impact of entrepreneurship education and training on entrepreneurship perception and intention: Study of educational system of Iran. Education and Training, 55(8-9), 868-885. https://doi.org/10.1108/ET-04-2013-0053

Fayolle, A. (2013). Personal views on the future of entrepreneurship education. Entrepreneurship \& Regional Development, 25(7-8), 692-701.

Fayolle, A., \& Gailiy, B. (2008). From craft to science Teaching models and learning processes in entrepreneurship education. Journal of European Industrial Training, 32(7), 569-593. https://doi.org/10.1108/03090590810899838

Fayolle, A., \& Gailiy, B. (2015). The impact of Entrepreneurship education on Entrepreneurial Attitudes and Intention: Hysteresis and Persistence. Journal OfSmall Business Management, 53(1), 75-93. https://doi.org/10.1111/jsbm.12065

Fayolle, A., Gailly, B., \& Lassas-Clerc, N. (2006). Assessing the impact of entrepreneurship education programmes : a new methodology. Journal of European Industrial Training, 30(9), 701-720. https://doi.org/10.1108/03090590610715022

Fayolle, A., Verzat, C., \& Wapshott, R. (2016). In quest of legitimacy: The theoretical and methodological foundations of entrepreneurship education research. International Small Business Journal: Researching Entrepreneurship, 34(7), 895-904. https://doi.org/10.1177/0266242616649250

Fiet, J. O. (2000a). The pedagogical side of entrepreneurship theory. Journal of Business Venturing, 16, 101-117.

Fiet, J. O. (2000b). The theoretical side of teaching entrepreneursip. Journal of Business Venturing, 16(99), 1-24.

Frank, H., \& Hatak, I. (2014). Doing a research literature review. In A. Fayolle \& M. Wright (Eds.), How to Get Published in the Best Entrepreneurship Journals: A Guide to Steer Your Academic Career (pp. 94-117). Edward Elgar Publishing. https://doi.org/10.4337/9781782540625 
Fretschner, M., \& Weber, S. (2013). Measuring and understanding the effects of entrepreneurial awareness education. Journal of Small Business Management, 51(3), 410-428. https://doi.org/10.1111/jsbm.12019

Gabrielsson, J., Hägg, G., Landström, H., \& Politis, D. (2020). Connecting the past with the present: the development of research on pedagogy in entrepreneurial education. Education and Training, 62(9), 1061-1086. https://doi.org/10.1108/ET-11-2019-0265

Galvão, A., Ferreira, J. J., \& Marques, C. (2018). Entrepreneurship education and training as facilitators of regional development: A systematic literature review. Journal of Small Business and Enterprise Development, 25(1), 17-40. https://doi.org/10.1108/JSBED05-2017-0178

Galvão, A., Marques, C. S., Ferreira, J., Galvão, A., \& Marques, C. S. (2019). Evaluation of an entrepreneurship training programme : a proposal for new guidelines. Education + Training, 61(2), 136-152. https://doi.org/10.1108/ET-11-2018-0228

Galvão, A., Mascarenhas, C., Gouveia Rodrigues, R., Marques, C. S., \& Leal, C. T. (2017). A quadruple helix model of entrepreneurship, innovation and stages of economic development. Review of International Business and Strategy, 27(2), 261-282. https://doi.org/10.1108/RIBS-01-2017-0003

Gangi, Y. A. (2017). The role of entrepreneurship education and training on creation of the knowledge economy. World Journal of Entrepreneurship, Management and Sustainable Development, 13(4), 375-388. https://doi.org/10.1108/wjemsd-06-20170032

Gedeon, S. A. (2017). Measuring Student Transformation in Entrepreneurship Education Programs. Education Research International, 2017, 1-12. https://doi.org/10.1155/2017/8475460

Gibb, A. (2002). In pursuit of a new ' enterprise' and paradigm for learning: creative destruction, new values, new ways of doing things and new combinations of knowledge. International Journal of Management Reviews, 4(3), pp.233-269.

Gorman, G, Hanlon, D., \& King, W. (1997). Some Research Perspectives on Entrepreneurship Education, Enterprise Education and Education for Small Business Management: A Ten-Year Literature Review. International Small Business Journal, 15(3), 56-77.

Graevenitz, G. von, \& Weber, R. (2009). The Effects of Entrepreneurship Education. Discussion Paper No. 269 The Effects of Entrepreneurship Education, 49(269), 1-46. 
Gruenwald, R. K. (2014). Alternative Approaches in Evaluating the EU SME Policy: Answers to the Question of Impact and Legitimization. Entrepreneurial Business and Economics Review, 2(2), 77-88. https://doi.org/10.15678/eber.2014.020207

Gustafsson-Pesonen, A., \& Remes, L. (2012). Evaluation of entrepreneurial development coaching: changing the Teachers' thinking and action on entrepreneurship. Annals of Innovation \& Entrepreneurship, 3(1), 17211. https://doi.org/10.3402/aie.v3i0.17292

Hägg, G., \& Gabrielsson, J. (2020). A systematic literature review of the evolution of pedagogy in entrepreneurial education research. In International Journal of Entrepreneurial Behaviour and Research (Vol. 26, Issue 5, pp. 829-861). Emerald Group Holdings Ltd. https://doi.org/10.1108/IJEBR-04-2018-0272

Heinonen, J., \& Hytti, U. (2016). Entrepreneurship mission and content in Finnish policy programmes. 23(1), 149-162. https://doi.org/10.1108/JSBED-10-2014-0170

Huang-Saad, A. Y., Morton, C. S., \& Libarkin, J. C. (2018). Entrepreneurship Assessment in Higher Education: A Research Review for Engineering Education Researchers. Journal of Engineering Education, 107(2), 263-290. https://doi.org/10.1002/jee.20197

Interman. (1992). Interman, International Management Development Network in Cooperation with the United Nations Development Program (UNDP) and the International Labor Office (ILO). (1992). Networking for Entrepreneurship Development, Geneva: International Labor Office.

Jeng, D. J. F., \& Hung, T. H. (2019). Comeback of the failed entrepreneur: An integrated view of costs, learning, and residual resources associated with entrepreneurial failure. Journal of Small Business Strategy, 29(1), 23-35.

Jessica, M., \& Menold, M. (2015). Exploring the Impact of Cognitive Preferences on Student Receptivity to De-sign Thinking (2015). 122nd ASEE Annual Conferenc and Exposition, 1-18.

Jones, C. (2010). Entrepreneurship education : revisiting our role and its purpose. Journal of Small Business \& Enterprises Development, 17(4), 500-513. https://doi.org/10.1108/14626001011088697

Jones, C., \& English, J. (2004). A contemporary approach to entrepreneurship education. Education + Training, 46(8/9), 416-623. https://doi.org/10.1108/00400910410569533

Kakouris, A., \& Georgiadis, P. (2016). Analysing entrepreneurship education: a bibliometric survey pattern. Journal of Global Entrepreneurship Research, 6(1). https://doi.org/10.1186/s40497-016-0046-y 
Evaluations of an entrepreneurship development program: A systematic literature review by Ronal Ferdilan, Wawan Dhewanto, Sonny Rustiadi

Karlan, D., \& Valdivia, M. (2011). Teaching entrepreneurship: impact of business training on microfinance clients and institutions. The Review of Economics and Statistics, 93(2), $510-527$.

Katz, J. A. (2003). The chronology and intellectual trajectory of American entrepreneurship education 1876-1999. Journal of Business Venturing, 18, 283-300. https://doi.org/10.1016/S0883-9026(02)00098-8

Khyareh, M. M., Khairandish, M., \& Torabi, H. (2018). Macroeconomic Effects of Entrepreneurship: Evidence from factor, efficiency and iinovation driven countries. International Journal of Entrepreneurship, 23(1), 1-21.

Klingler-vidra, R., Pardo, R. P., \& Klingler-vidra, R. (2019). Beyond the Chaebol? The Social Purpose of Entrepreneurship Promotion in South Korea Beyond the Chaebol? The Social Purpose of Entrepreneurship Promotion in South Korea. Asian Studies Review, 43(4), 637-656. https://doi.org/10.1080/10357823.2019.1663576

Kolvereid, L., \& Moen, Ø. (1997). Entrepreneurship among business graduates: does a major in entrepreneurship make a difference? Journal of European Industrial Training, 21(4), 154-160. https://doi.org/10.1108/03090599710171404

Krueger, N. F., Reilly, M. D., \& Carsrud, A. L. (2000). Competing models of entrepreneurial intentions. Journal of Business Venturing, 15, 411-432.

Kumar, H. M. (2017). Role of Entrepreneurial Development Programmes in Growth of Entrepreneurship in India. International Journal of Latest Technology in Engineering, Management \& Applied Science (IJLTEMAS), VI(VI), 1-1.

Kuratko, D. F. (2005). The Emergence of Entrepreneurship Education: Development, Trends, and Challenges. ET\& $P, 1042-2587,577-597$.

Kyrö, P. (2015). The conceptual contribution of education to research on entrepreneurship education. Entrepreneurship and Regional Development, 27(9-10), 599-618. https://doi.org/10.1080/08985626.2015.1085726

Lackéus, M. (2015). Entrepreneurship in Education: What, Why, When, How. Paris: OECD. In $O E C D$.

Landra, N. S., I Ketut Setuia Sudja, I Nengah, \& Arizona, P. E. (2018). Enterpreneurship Development Program for the improvement of the Student at Mahasaraswati University Denpasar. International Journal of Sustainabillity, Education and Global Creative Economic, 1(1), 75-78.

Landström, H., \& Harirchi, G. (2018). The social structure of entrepreneurship as a scientific field. Research Policy, 47(3), 650-662. https://doi.org/10.1016/j.respol.2018.01.013 
Larso, D., Mirzanti, I. R., \& Simatupang, T. M. (2018). Evaluation of emerging entrepreneurship policy. International Journal of Economic Policy in Emerging Economies, 11(1/2), 49. https://doi.org/10.1504/ijepee.2018.10012090

Leonidou, E., Christofi, M., Vrontis, D., \& Thrassou, A. (2020). An integrative framework of stakeholder engagement for innovation management and entrepreneurship development. $\begin{array}{llll}\text { Journal of } & \text { Business }\end{array}$ https://doi.org/10.1016/j.jbusres.2018.11.054

Liñán, F., Rodríguez-Cohard, J. C., \& Rueda-Cantuche, J. M. (2011). Factors affecting entrepreneurial intention levels: A role for education. International Entrepreneurship and Management Journal, 7(2), 195-218. https://doi.org/10.1007/s11365-010-0154-Z

Loi, M., Castriotta, M., \& di Guardo, M. C. (2016). The theoretical foundations of entrepreneurship education: How co-citations are shaping the field. International Small Business Journal: Researching Entrepreneurship, 34(7), 948-971. https://doi.org/10.1177/0266242615602322

Lundström, A., Vikström, P., Fink, M., Meuleman, M., Glodek, P., Storey, D., \& Kroksgård, A. (2014). Measuring the Costs and Coverage of SME and Entrepreneurship Policy: A Pioneering Study. Entrepreneurship: Theory and Practice, 38(4), 941-957. https://doi.org/10.1111/etap.12037

Martin, B. C., McNally, J. J., \& Kay, M. J. (2013). Examining the formation of human capital in entrepreneurship: A meta-analysis of entrepreneurship education outcomes. Journal of Business Venturing, 28(2), 211-224. https://doi.org/10.1016/J.JBUSVENT.2012.03.002

Martínez, A. C., Puentes, E., \& Ruiz-Tagle, J. (2018). The effects of micro-entrepreneurship programs on labor market performance: Experimental evidence from Chile. American Economic Journal: Applied Economics, 10(2), 101-124. https://doi.org/10.1257/app.20150245

Massaro, M., Dumay, J., \& Guthrie, J. (2016). On the shoulders of giants: undertaking a structured literature review in accounting. Accounting, Auditing \& Accountability Journal, 29(5), 767-801. https://doi.org/10.1108/AAAJ-01-2015-1939

Matlay, H. (2008). The impact of entrepreneurship education on entrepreneurial outcomes. Journal of Small Business and Enterprise Development, 15(2), 382-396. https://doi.org/10.1108/14626000810871745 
Evaluations of an entrepreneurship development program: A systematic literature review by Ronal Ferdilan, Wawan Dhewanto, Sonny Rustiadi

Matlay, H. (2011). The influence of stakeholders on developing enterprising graduates in UK HEIs. International Journal of Entrepreneurial Behaviour and Research, 17(2), 166182. https://doi.org/10.1108/13552551111114923

Matlay, H., \& Carey, C. (2007). Entrepreneurship education in the UK: A longitudinal perspective. In Journal of Small Business and Enterprise Development (Vol. 14, Issue 2, pp. 252-263). https://doi.org/10.1108/14626000710746682

Matlay, H., Carey, C., Matlay, H., \& Carey, C. (2009). Entrepreneurship education in the UK : a longitudinal perspective. Journal of Small Business \& Enterprises Development, 14(2), 252-263.

Nabi, G., Liñán, F., Fayolle, A., Krueger, N., \& Walmsley, A. (2017). The impact of entrepreneurship education in higher education: A systematic review and research agenda. Academy of Management Learning \& Education , 16(2), 1-42.

Neergaard, H. , R. S. , \& J. S. (2014). Identity transformation: Learning entrepreneurship through pedagogical nudging. Paper presented at Institute for Small Business and Entrepreneurship, Manchester, United Kingdom.

Nyadu-Addo, R., \& Mensah, M. S. B. (2018). Entrepreneurship education in Ghana - the case of the KNUST entrepreneurship clinic. Journal of Small Business and Enterprise Development, 25(4), 573-590. https://doi.org/10.1108/JSBED-02-2017-0062

Oosterbeek, H., Ã, M. V. P., \& Ijsselstein, A. (2010). The impact of entrepreneurship education on entrepreneurship skills and Motivation. European Economic Review, 54(3), 442-454. https://doi.org/10.1016/j.euroecorev.2009.08.002

Palomba, C., \& Banta, T. W. (1999). Assessment Essentials: Planning, Implementing, and Improving Assessment in Higher Education. Jossey-Bass, Inc.

Pettersson, K., Ahl, H., Berglund, K., \& Tillmar, M. (2017). In the name of women? Feminist readings of policies for women's entrepreneurship in Scandinavia. Scandinavian Journal of Management, 33(1), 50-63. https://doi.org/10.1016/j.scaman.2017.01.002

Pittaway, L. (2016). Entrepreneurship Education: A Systematic Review of the Evidence. October 2007. https://doi.org/10.1177/0266242607080656

Pittaway, L., \& Cope, J. (2007). Entrepreneurship education: A systematic review of the evidence. In International Small Business Journal (Vol. 25, Issue 5, pp. 1-33). https://doi.org/10.1177/0266242607080656

Prieger, J. E., Bampoky, C., Blanco, L. R., \& Liu, A. (2016). Economic Growth and the Optimal Level of Entrepreneurship. World Development, 82, 95-109. https://doi.org/10.1016/J.WORLDDEV.2016.01.013 
Primanto, A. B., Khoirul Abs, M., \& Slamet, A. R. (2018). A Study of The Best Selling Smartphone in The Two Biggest Marketplace in Indonesia. Jurnal Terapan Manajemen Dan Bisnis, 4, 17-24.

Purzer, S., Fila, N., \& Nataraja, K. (2016). Evaluation Of Current Assessment Methods In Engineering. Anvances in Engineering Education, Winter, 1-27.

Rauch, A., \& Hulsink W. (2015). Putting Entrepreneurship Education Where the Intention to Act Lies: An Investigation Into the Impact of Entrepreneurship Education on Entrepreneurial Behavior. Academy of Management Learning \& Education, 14(2), 187204.

Rustiadi, S., \& Arina, N. (2019). Indonesia weaving culture innovation: a study of collaboration and individual actors. Jurnal Kewirausahaan Dan Bisnis, 24(14), 66-80.

Sánchez, J. C. (2013). The impact of an entrepreneurship education program on entrepreneurial competencies and intention. Journal of Small Business Management, 51(3), 447-465. https://doi.org/10.1111/jsbm.12025

Shane, S., \& Venkataraman, S. (2000). The promise of entrepreneurship as a field of research. Academy of Management Review, 25(1), 217-226.

Shane, S., \& Venkataraman, S. (2012). Note as the promise of entrepreneurship. The Academy of Management Review, 25(1), 217-226.

Solomon G. (2007). An examination of entrepreneurship education in the United States. Journal of Small Business and Enterprise Development, 14(2), 168-182. https://doi.org/10.1108/14626000710746637

Song, L., \& Winkler, C. (2014). China's trans-regional entrepreneurship: A panel data analysis of 31 provinces. Journal of Entrepreneurship in Emerging Economies, 6(3), 202-222. https://doi.org/10.1108/JEEE-06-2014-0020

Souitaris, V., Zerbinati, S., \& Al-laham, A. (2007). Do entrepreneurship programmes raise entrepreneurial intention of science and engineering students? The effect of learning, inspiration and resources. 22, 566-591. https://doi.org/10.1016/j.jbusvent.2006.05.002

Stoica, O., \& Roman, A. (2020). The Nexus between Entrepreneurship and Economic Growth: A Comparative Analysis on Groups of Countries.

Sudha, B. (2019). Entrepreneurship and Economic Development. International Journal of Multidisciplinary Reserch Review, 1(10), 194-197. https://www.researchgate.net/publication/332092174

Suminar, T., Arbarini, M., \& Loretha, A. (2021). Management of Entrepreneurship Training Program in Literacy Village. 
Terjesen, S., Bosma, N., \& Stam, E. (2016). Advancing Public Policy for High-Growth, Female, and Social Entrepreneurs. Public Administration Review, 76(2), 230-239. https://doi.org/10.1111/puar.12472

Thomas, A., \& Mueller, S. (2000). A Case f or Comparative Entrepreneurship: Assessing the Relevance of Culture. Journal of International Business Studies, 31(2), 287-301.

Tonkovic, Edward Veckie, \& Vlado Walter Veckie. (2015). Aplications Of Penta Helix Model In Economic Development," Economy of eastern Croatia yesterday, today, tommorow, Josip Juraj Strossmayer University of Osijek, Faculty of Economics, Croatia, 4, 385-393.

Tranfield, D., Denyer, D., \& Smart, P. (2003). Towards a Methodology for Developing Evidence-Informed Management Knowledge by Means of Systematic Review. British Journal of Management, 14, 207-222.

Tsai, W. H., Lee, P. L., Shen, Y. S., \& Hwang, E. T. Y. (2014). A combined evaluation model for encouraging entrepreneurship policies. Annals of Operations Research, 221(1), 449-468. https://doi.org/10.1007/s10479-011-1029-6

Valerio, A., Parton, B., \& Robb, A. (2014). Entrepreneurship Education and Training Programs around the World Dimensions for Success. Washington, DC: World Bank.

Vesper, H., \& Gartner, B. (1997). Executive forum Measuring progress in entrepreneurship education. Journal Of Business Venturing, 12, 403-421.

Wan, V. (1989). The Enterprise Workshop Programme in Australia. International Small Business Journal, 7(2), 23-34.

Warhuus, J. P., Tanggaard, L., Robinson, S., \& Ernø, S. M. (2017). From I to We: collaboration in entrepreneurship education and learning? Education and Training, 59(3), 234-249. https://doi.org/10.1108/ET-08-2015-0077 